\title{
Wartość pracy dla pracujących osób pozbawionych wolności
}

\section{Wstęp}

Praca jest dobrem człowieka - dobrem jego człowieczeństwa - przez pra„/ cę bowiem człowiek nie tylko przekształca przyrodę, dostosowując ją do swoich potrzeb, ale także urzeczywistnia siebie jako człowiek, a także poniekąd bardziej staje się człowiekiem"'. Te słowa Jana Pawła II przypominają, że praca jest niezwykle istotną częścią ludzkiego życia. Niezależnie od przyjętej perspektywy, zwraca się uwagę na jej wielowymiarowość. Analizując jej znaczenie nie powinno się redukować jej wyłącznie do jednego aspektu. Praca wykonywana przez więźniów odznacza się inną specyfiką niż podejmowana w warunkach wolnościowych. Celem prowadzonych analiz jest próba określenia, jak pracujące osoby pozbawione wolności postrzegają wartość pracy i jakie znaczenie jej przypisują. Dzięki temu możliwe jest adekwatne kształtowanie oddziaływań penitencjarnych i skoncentrowanie wysiłków na tych elementach, które przynoszą wymierne efekty.

\section{Wartość pracy ludzkiej}

Praca ludzka jest zjawiskiem analizowanym przez różne dziedziny i dyscypliny naukowe. Można ją opisać za pomocą wzoru, jak i podjąć próby skoncentro-

* Dr Katarzyna Lenart-KŁoś - Katolicki Uniwersytet Lubelski Jana Pawła II, Wydział Nauk Społecznych, email: katarzyna.lenart-klos@kul.pl, ORCID 0000-0001-6429-6152.

${ }^{1}$ Jan Paweł II, Laborem exercens, 1981, s. 9. 
wania się na aspektach psychologicznych czy religijnych. Mimo to podkreśla się złożoność procesu, jakim jest praca ludzka, rozumiana jako jedna ze sfer życia ludzi.

Klasyczne, wąskie ujęcie pracy opisuje ją jako działalność zarobkową. Szersze, nieklasyczne określenie pracy ujmuje ją z jednej strony jako działanie podejmowane z konieczności (w sensie zarobkowym), ale również jako pracę wykonywaną dobrowolnie, która jest konsekwencją istoty natury ludzkiej i chęci samorealizacji. Podejście nieklasyczne odnosi się do tego, że wykonywana praca jest podyktowana potrzebami społecznymi, ale również ograniczona kontekstem społecznym, a przy tym cechuje się brakiem elementów przymusu czy kary². Jeśli praca jest narzucana człowiekowi, może to prowadzić do alienacji człowieka wobec pracy. Praca nie przynosi wówczas satysfakcji. Takie sytuacje czasami występują w przypadku pracy więźniów³. Alienacja, czyli swoiste wyobcowanie jednostki z procesu pracy, a nawet brak identyfikacji z pracą, stanowi w tym kontekście konsekwencję jej przymusowego charakteru. W przypadku pracy podejmowanej przez osoby pozbawione wolności taka alienacja może wynikać również z ograniczonych możliwości wyboru pracy zgodnej z kwalifikacjami czy odpowiadającej kompetencjom i ambicjom pracownika. Odpowiedzią na procesy alienacji jest postulat humanizacji pracy, czyli przeciwdziałania degradacji człowieka w procesie pracy i dostosowania pracy do człowieka ${ }^{4}$. Postulat ten jest trudny do realizacji w warunkach izolacji penitencjarnej, ale jednym z przejawów jego uwzględnienia stało się skoncentrowanie wysiłków na udostępnieniu możliwości pracy coraz szerszym grupom więźniów jako podstawowego środka resocjalizacji.

Dążenia do humanizacji pracy czy wyzbycia się alienacji człowieka pracującego wpisują się w nurt personalizmu. Czesław Strzeszewski analizował pracę w kategoriach działalności człowieka, która z jednej strony jest wolna, z drugiej zaś naturalnie konieczna. Wynika ona przede wszystkim z poczucia obowiązku, wiąże się z trudem i radością, a za cel stawia sobie tworzenie wartości o charakterze materialnym i duchowym, które są użyteczne społecznie ${ }^{5}$. Personalistyczne ujęcie pracy, w którym człowiek - jako jej podmiot - jest najważniejszy, wskazuje na konieczność integralnego traktowania tego procesu. Praca jest złożoną wartością: dzięki niej człowiek się rozwija i staje się bardziej człowiekiem. Celem pracy jest wszechstronny rozwój osoby ludzkiej. Oprócz tego praca stanowi wartość moralną, ponieważ za jej sprawą człowiek zdobywa

2 W. Sztumski, Nieklasyczne podejście do pracy i bezrobocia, w: Praca a bezczynność zawodowa, red. Z. Stachowski, Tyczyn 2004, s. 28-29.

3 J. Sztumski, Socjologia pracy, Katowice 1999, s. 32-33.

4 Por. B. Bombała, Od humanizacji i strukturalizacji pracy do upełnomocniania pracowników - aspekt etyczny, „Annales. Etyka w życiu gospodarczym” 2011, nr 1, s. 67-68.

5 Cz. Strzeszewski, Katolicka nauka społeczna, Lublin 1994, s. 580. 
sprawności moralne. Przez sumienne wykonywanie zadań wywiązuje się on z obowiązków wobec samego siebie i innych ludzi. Społeczny wymiar pracy oznacza, że człowiek nie pracuje sam i tylko dla siebie. Podczas realizowania zadań zawodowych tworzą się więzi społeczne. Ponadto należy wskazać na pracę jako wartość kulturalną - obejmuje ona bowiem twórcze działanie i myśli człowieka, dzięki czemu możliwe jest tworzenie kultury. W wymiarze religijnym praca jest sposobem wypełniania Bożego powołania do czynienia sobie ziemi poddaną. Natomiast jej wartość gospodarcza opiera się na założeniu, że dzięki efektom pracy człowiek może zaspokajać swe potrzeby i przyczyniać się do poprawy warunków życia ${ }^{6}$. Jerzy Stępień w sposób szczególny odnosi się do czterech aspektów pracy ludzkiej: filozoficznego, historycznego, społecznego i ekonomicznego. W sensie filozoficznym osoba ludzka dąży poprzez pracę do osiągnięcia preferowanych wartości, zarówno jednostkowych, jak i społecznych. Historyczny wymiar pracy skłania do dostrzeżenia zmian, które w tym obszarze zaszły, takimi jak podejście do pracy i sposoby jej wykonywania. Stępień zwraca uwagę, że w aspekcie społecznym należy traktować pracę jako proces uwarunkowany kulturowo, który pozwala na rozwój człowieka, zaś w sensie ekonomicznym przynosi realne korzyści materialne i finansowe, co jest podstawą dobrobytu społeczeństwa7. Wymiary pracy, wzajemnie się uzupełniające, pozwalają analizować ją jako wartość. Zygmunt Wiatrowski, który również określa pracę jako szczególną wartość, twierdzi, że dzięki niej powstają i funkcjonują społecznie inne wartości ${ }^{8}$. Podobnie uważają inni badacze $^{9}$. Pracę jako wartość można ująć w odniesieniu do koncepcji Stanisława Ossowskiego, który wyróżnia wartości instrumentalne (wartości-środki) i autoteliczne (wartości-cele). Wartości instrumentalne mają charakter pomocniczy i stanowią pożądany sposób postępowania, by możliwe było osiągnięcie celu. Natomiast wartości autoteliczne są stanami docelowymi. Wiążą się z rozwojem i zadowoleniem $\mathrm{z}$ tego, kim człowiek jest i co robi. Wartości-cele powodują materialne i duchowe doskonalenie człowieka ${ }^{10}$. Praca może być zatem traktowana jako środek do osiągnięcia celu, ale też jako cel, który przyczynia się do rozwoju osoby ludzkiej.

Badania CBOS pokazują, że praca nieco straciła na znaczeniu na przestrzeni lat i w hierarchii wartości Polaków można zaobserwować spadek jej wagi (2008

${ }^{6}$ F.J. Mazurek, Godność osoby ludzkiej podstawa praw człowieka, Lublin 2001, s. 337-338.

J. Stępień, Socjologia pracy i zawodu, Poznań 2001, s. 18.

8 Z. Wiatrowski, Praca jako wartość uniwersalna i jako problem XXI wieku, w: Praca człowieka jako kategoria współczesnej pedagogiki, red. W. Furmanek, Rzeszów-Warszawa 2007, s. 54.

9 Por. D. Dobrowolska, Praca zawodowa jako wartość w życiu jednostki, w: Problematyka i metody badań nad zadowoleniem z pracy, red. A. Sarapata, Wrocław 1973, s. 9-33; U. Bejma, Praca jako wartość w życiu człowieka. Wybrane aspekty, „Periodyk Naukowy Akademii Polonijnej” 2015, nr 4, s. 47-73.

10 S. Ossowski, Z zagadnień psychologii społecznej. Dzieła, T. 3, Warszawa 1967, s. 71-101. 
- 44\%, 2013 - 41\%, 2019 - 36\%)" Niezmiennie z całego spektrum wartości najbardziej cenione jest szczęście rodzinne, dobre zdrowie, spokój i uczciwe życie. Natomiast ważniejsze od pracy w opinii Polaków staje się grono przyjaciół czy szacunek innych ludzi ${ }^{12}$. Nieco inaczej przedstawia się kwestia pracy i postaw wobec niej w sytuacji izolacji penitencjarnej, gdzie przede wszystkim ma ona wymiar resocjalizacyjny.

\section{Praca więźniów jako element resocjalizacji}

W polskim systemie penitencjarnym nastąpiły zmiany w różnych obszarach. Praca świadczona przez osoby pozbawione wolności przestała stanowić środek odwetu na sprawcach przestępstw, stała się głównie narzędziem wychowawczym i resocjalizacyjnym ${ }^{13}$. Polskie prawo uwzględnia w przepisach rekomendacje europejskie. Osobliwe sformułowanie zawierają chociażby rekomendacje Komitetu Ministrów państw członkowskich Rady Europy, w których zaznaczono, że „praca więźniów traktowana jest jako pozytywny element rygoru więziennego i nigdy nie jest używana jako kara" ${ }^{14}$. Rygor więzienny budzi skojarzenia pejoratywne i trudno w nim doszukać się pozytywnych elementów. Wprawdzie obowiązujący Kodeks karny wykonawczy (KKW) unika słowa „resocjalizacja” i zastępuje je sformułowaniem „wzbudzanie w skazanym woli współdziałania w kształtowaniu jego społecznie pożądanych postaw, w szczególności poczucia odpowiedzialności oraz potrzeby przestrzegania porządku prawnego i tym samym powstrzymania się od powrotu do przestępstwa"15, lecz zwłaszcza w ostatnich latach praca stała się jednym $\mathrm{z}$ najważniejszych rodzajów wpływu na osoby pozbawione wolności ${ }^{16}$. Znalazło to wyraz w realizowanym od 2016 roku programie „Praca dla więźniów”, którego celem jest aktywizacja zawodowa tej grupy społecznej. Program przewiduje budowę 40 hal produkcyjnych, poszerzenie możliwości nieodpłatnej pracy skazanych na

${ }^{11}$ Rodzina - jej znaczenie i rozumienie. Komunikat z badań CBOS, 2019, nr 22, s. 2-3.

12 Tamże.

13 D. Pstrąg, Praca w procesie readaptacji społecznej skazanych, „Lubelski Rocznik Pedagogiczny” 2014, t. 33, s. 148-151.

14 Pkt. 26.1 Zaleceń Rec (2006) 2 Komitetu Ministrów państw członkowskich Rady Europy w sprawie Europejskich Reguł Więziennych przyjętych przez Komitet Ministrów w dniu 11 stycznia 2006 r.

15 Art. 67 \$ 1 Ustawy z dnia 6 czerwca 1997 r. - Kodeks karny wykonawczy (Dz.U. 1997 nr 90 poz. 557).

16 Art. $67 \$ 3 \mathrm{KKW}$ : „W oddziaływaniu na skazanych, przy poszanowaniu ich praw i wymaganiu wypełniania przez nich obowiązków, uwzględnia się przede wszystkim p r a c ę [podkr. K.L.-K.], zwłaszcza sprzyjającą zdobywaniu odpowiednich kwalifikacji zawodowych, nauczanie, zajęcia kulturalno-oświatowe i sportowe, podtrzymywanie kontaktów z rodziną i światem zewnętrznym oraz środki terapeutyczne”. 
rzecz samorządów terytorialnych, jak również ulgi dla pracodawców zatrudniających więźniów. Budowa hal jest finansowana ze środków zgromadzonych na Funduszu Aktywizacji Zawodowej Skazanych oraz Rozwoju Przywięziennych Zakładów Pracy pochodzących z potrąceń z wynagrodzeń skazanych ${ }^{17}$. Średnie zatrudnienie więźniów w roku 2019 kształtowało się na poziomie 55,7\%, w tym 17055 osób pracujących odpłatnie i 19835 nieodpłatnie (średnia liczba osadzonych w 2019 roku wynosiła 74564$)^{18}$. Dla porównania w roku 2015, czyli przed zainicjowaniem programu „Praca dla więźniów”, średnie zatrudnienie osób pozbawionych wolności oscylowało wokół 35,5\%, pracę odpłatną wykonywało 10024 osoby, nieodpłatną zaś 14737 (przy średniej liczbie osadzonych za rok 2015 na poziomie 74814 osób) ${ }^{19}$. Zgodnie z art. $121 \$ 1$ KKW skazanemu zapewnia się świadczenie pracy, o ile jest to możliwe. Nie każdy osadzony będzie mógł podjąć zatrudnienie, więc w niektórych zakładach karnych praca nadal stanowi przywilej. Jednocześnie KKW wskazuje na kolejność zatrudniania osób pozbawionych wolności. Przede wszystkim należy zapewnić pracę skazanym mającym zobowiązania alimentacyjne, a także borykającym się z wyjątkowo trudną sytuacją finansową, osobistą czy rodzinną ${ }^{20}$. Praca podejmowana przez osoby pozbawione wolności jest odpłatna ${ }^{21}$, za wyjątkiem sytuacji wskazanych w KKW, kiedy można zlecić prace pomocnicze, porządkowe lub na cele społeczne w wymiarze do 90 godzin w miesiącu bez wynagrodzenia ${ }^{22}$. Przydzielanie pracy osobom posiadającym zobowiązania sprawia, że nabiera ona charakteru obligatoryjnego i akcent przesuwa się z traktowania jej jako przywileju w kierunku postrzegania jej jako obowiązku człowieka. KKW również ujmuje pracę jako obowiązek, zarówno tę o charakterze odpłatnym, jak i nieodpłatnym ${ }^{23}$. Jako że jednym $\mathrm{z}$ celów oddziaływań penitencjarnych jest kształtowanie postaw społecznych, które są powszechnie akceptowane, wymaganie od skazanych, by ponosili odpowiedzialność za posiadane długi czy zobowiązania wobec innych wydaje się być sprawiedliwe i adekwatne do wytycznych w tym zakresie.

17 P. Jaki, Zatrudnienie skazanych $w$ Polsce na tle porównawczym. Zagadnienia wybrane, „Przegląd Więziennictwa Polskiego" 2017, nr 95, s. 79-98.

18 Roczna Informacja Statystyczna za rok 2019, online: https://sw.gov.pl/strona/statystyka-roczna [dostęp: 25 maja 2020].

19 Roczna Informacja Statystyczna za rok 2015, online: https://sw.gov.pl/strona/statystyka-roczna [dostęp: 25 maja 2020].

20 Art. $122 \$ 2 \mathrm{KKW}$.

${ }^{21}$ Art. $123 \$ 1 \mathrm{KKW}$.

22 Art. 123a $\$ 1 \mathrm{KKW}$.

${ }^{23}$ Art. $116 \$ 1$ KKW: „Skazany ma obowiązek: [...] pkt. 4 - wykonywania pracy, jeżeli przepisy szczególne, także wynikające z prawa międzynarodowego, nie przewidują zwolnienia od tego obowiązku, oraz wykonywania prac, o których mowa w art. 123a $\$ 1$ (pracy nieodpłatnej - przyp. K.L.-K.)”. 


\section{Praca jako sposób przeciwdziałania prizonizacji}

Praca może być też rozpatrywana $\mathrm{w}$ kategoriach narzędzia służącego profilaktyce zjawisk występujących w izolacji penitencjarnej bądź będących jej skutkiem. Jednym z nich jest prizonizacja.

Donald Clemmer, twórca pojęcia prizonizacji, definiuje go jako przyjmowanie, w większym lub mniejszym stopniu, tradycyjnych sposobów funkcjonowania, zwyczajów i ogólnej kultury więzienia ${ }^{24}$. Clemmer wskazuje na uwarunkowania sprzyjające prizonizacji i nazywa je „uniwersalnymi czynnikami prizonizacji” ${ }^{25}$. Wśród nich wymienia znaczenie akceptacji przez więźnia jego roli jako podwładnego, nagromadzenia faktów dotyczących organizacji zakładu karnego, kształtowanie nowych nawyków związanych z ubiorem, jedzeniem czy pracą, a także posługiwanie się specyficznym językiem ${ }^{26}$. Wskazane czynniki mają charakter uniwersalny, ponieważ każda uwięziona osoba ma z nimi styczność. Nie oznacza to jednak, że wszyscy ulegają prizonizacji w jednakowym stopniu. Zależy to przede wszystkim od osobowości skazanego. Istotne są także relacje więźnia poza murami, jak również akceptacja więziennej kultury ${ }^{27}$. Z badań zrealizowanych przez Stanisława Małka wynika, że skazani uczestniczący w podkulturze więziennej, szczególnie recydywiści, są bardziej podatni i łatwiej asymilują się do warunków izolacji. Brak pracy podczas odbywania kary pozbawienia wolności sprzyja prizonizacji i tym samym nie kształtuje pozytywnego stosunku do pracy po zakończeniu kary ${ }^{28}$. Joanna Klimczak, która badała proces prizonizacji wśród więźniów z dożywotnimi wyrokami, zwraca uwagę, że praca jest ważnym elementem wypełniającym czas. Dla takich osób stanowiła ona najbardziej pożądane zajęcie. Respondenci wyrażali chęć podjęcia przede wszystkim płatnego zatrudnienia, ale dla niektórych praca nieodpłatna była wystarczająca ${ }^{29}$. Prizonizacji sprzyja również niski poziom satysfakcji z różnych aspektów życia. Skazani, którzy są niezadowoleni z relacji z bliskimi, swojego stanu zdrowia czy sytuacji ekonomicznej, będą próbowali zrekompensować sobie braki przez pełniejszą integrację ze środowiskiem więziennym ${ }^{30}$.

24 D. Clemmer, The Prison Community, New York 1940, s. 270.

25 D. Clemmer, Observations on Imprisonment as a Source of Criminality, „Journal of Criminal Law and Criminology" 1950, nr 3, s. 316.

26 Tamże.

27 Tamże, s. 317.

28 S. Małek, Prizonizacja w grupie mężczyzn odbywających karę pozbawienia wolności, „Przegląd Więziennictwa Polskiego" 2009, nr 64-65, s. 147-148.

29 J. Klimczak, Prizonizacja a skazani na karę dożywotniego pozbawienia wolności, „Archiwum Kryminologii” 2017, nr 39, s. 241.

30 B.A. Paterline, D. Orr, Adaptation to Prison and Inmate Self-Concept, „Journal of Psychology and Behavioral Science" 2016, nr 2, s. 74. 
Prizonizacja występuje w zakładach karnych, które Erving Goffman uważa za instytucje totalne. Stwarzają one większe ograniczenia niż pozostałe, przede wszystkim przez zastosowanie fizycznych barier uniemożliwiających kontakt $\mathrm{z}$ otoczeniem zewnętrznym ${ }^{31}$. Typologia strategii adaptacyjnych więźniów do warunków instytucji totalnych zaproponowana przez Goffmana wskazuje na pięć metod: wycofanie, bunt, zadomowienie, konwersję i zimną kalkulację². Wycofanie polega na utracie zainteresowania światem zewnętrznym i ograniczeniu działań do takich, które bezpośrednio dotyczą człowieka. Bunt oznacza bezkompromisowe odrzucanie reguł instytucji i odmowę współpracy z personelem. Zadomowienie wskazuje na stworzenie przez skazanego w warunkach izolacji swojego świata i takich elementów otoczenia, dzięki którym znikną napięcia. Jest to swoista próba stabilizacji własnej sytuacji życiowej. Konwersja to sposób pokazania personelowi uznania obowiązujących reguł, sposobu myślenia przełożonych i wejście w rolę dobrego, zdyscyplinowanego podwładnego. Natomiast najczęściej występuje zimna kalkulacja, czyli połączenie różnych technik i stosowanie odpowiedniego modelu w zależności od sytuacji33.

Dorota Kanarek-Lizik w swych badaniach porównała modele przystosowania się skazanych do warunków więziennych według klasyfikacji zaproponowanej przez Goffmana. Podjęła próbę rozróżnienia tych modeli wśród recydywistów i osób odbywających karę po raz pierwszy. W obu grupach najczęściej dominował model wycofania. Natomiast $32,2 \%$ recydywistów i aż $60 \%$ odbywających karę po raz pierwszy nie dokonało wyboru żadnego modelu adaptacji. Zdaniem Kanarek-Lizik wskazanie sposobu adaptacji wiąże się z mniejszymi szansami na resocjalizację. Intensywne działania należy więc skierować przede wszystkim do osób, które nie deklarują żadnego modelu przystosowania ${ }^{34}$.

Więźniowie, osoby opuszczające zakłady karne, przestępcy stanowią kategorie społeczne uznawane za podatne na wykluczenie społeczne. Jest to skutek wypadania na określony czas ze społecznie akceptowanej drogi życiowej i przyjęcia nowej roli w więzieniu. Próby powrotu do społeczności mogą zakończyć się sukcesem, ale też mogą prowadzić do odczuwania bezradności czy generowania postaw roszczeniowych ${ }^{35}$. Przeciwdziałanie wykluczeniu społecznemu więźniów czy byłych więźniów to zadanie polityki społecznej realizowanej w warunkach wolnościowych, ale również polityki penitencjarnej w jej części dotyczącej warunków odbywania kary pozbawienia wolności. Brak pracy stanowi zagro-

${ }^{31}$ E. Goffman, Charakterystyka instytucji totalnych, w: Współczesne teorie socjologiczne, T.1, red. A. Jasińska-Kania i in., Warszawa 2006, s. 316.

32 Tamże, s. 325-327.

33 Tamże.

${ }^{34}$ D. Kanarek-Lizik, Modele adaptacji skazanych do warunków więziennych - wyniki badań własnych, „Resocjalizacja Polska” 2013, nr 4, s. 209.

${ }_{35}$ Z. Woźniak, Programy i strategie polityki społecznej dla grup ryzyka, Warszawa 2019, s. 51-55. 
żenie samodzielności życiowej i stabilizacji - nie tylko ekonomicznej - (byłych) więźniów, którzy należą do grupy ryzyka. Umożliwianie pracy coraz szerszym kręgom osadzonych pozwala kształtować prawidłowe postawy wobec pracy i traktowanie jej jako wartości, która umożliwia osiąganie innych wartości.

\section{Metodologia badań własnych}

Badania socjologiczne zostały przeprowadzone w Areszcie Śledczym w Lublinie w okresie od grudnia 2019 roku do lutego 2020 roku z osobami osadzonymi, wykonującymi pracę na terenie lub poza zakładem karnym (zatrudnieni tymczasowo aresztowani oraz zatrudnieni odbywający karę pozbawienia wolności). Respondenci zostali wyłonieni w toku celowo-losowego doboru próby badawczej. Przeprowadzono sondaż diagnostyczny z użyciem autorskiego kwestionariusza ankiety. Ankietę uzupełniło 210 osadzonych. Próba badawcza składała się w 32,4\% z kobiet (68 osób) i w 67,6\% z mężczyzn (142 osób). Odpłatnie pracowało 49\% (103), nieodpłatnie 47,6\% (100), zaś 3,3\% ankietowanych nie udzieliło odpowiedzi (7). $64,3 \%$ badanych odbywało karę raz pierwszy (135), 34,3\% to recydywiści (72), 1,4\% nie odpowiedziało na to pytanie (3). Pod względem wieku grupa przedstawia się następująco: 3,8\% więźniów to osoby do 21 lat (3), 24,8\% w przedziale 22-30 lat (52), $52,4 \%$ inkarcerowanych w przedziale $31-45$ lat (110), 15,2\% w wieku $46-55$ lat (32) i 3,8\% osób w wieku 56 lat i więcej (8). 74,8\% badanych podjęło pracę na terenie jednostki penitencjarnej (157), 25,2\% pracuje na zewnątrz (53). Spośród respondentów 36,7\% zostało skierowanych do pracy (77), natomiast 63,3\% badanych zadeklarowało, że sami się zgłosili, by podjąć zatrudnienie (133).

Postawiono tezę, iż możliwość podjęcia pracy w trakcie odbywania kary pozbawienia wolności ma dla osadzonych dużą wartość. Zostały sformułowane dwie hipotezy szczegółowe.

H1. Więźniowie pracujący nieodpłatnie częściej traktują pracę jako uciążliwość niż więźniowie otrzymujący wynagrodzenie.

$\mathrm{H} 2$. Więźniowie podejmujący pracę z własnej inicjatywy rzadziej by z niej rezygnowali niż więźniowie, którym praca została narzucona.

\section{Wyniki badań własnych}

Postawiony problem badawczy ma na celu stwierdzenie, czym charakteryzuje się podejście osadzonych do pracy, czy ma dla nich charakter wyłącznie instrumentalny, czy może przypisują jej większą wartość.

Pierwsza część analiz dotyczy postrzegania pracy w kategoriach uciążliwości. Tylko 7,6\% respondentów uważa pracę za przykry obowiązek (odpowiedzi 
„zdecydowanie tak” i „raczej tak”), zaś 86,7\% skazanych (łącznie „zdecydowanie nie” i „raczej nie”) deklaruje, że praca nie jest dla nich ciężarem ( $\chi 2=221,333$; $\mathrm{p}=0,000$ ). Poniższa tabela uwzględnia wyniki w podziale ze względu na otrzymywanie lub brak wynagrodzenia za świadczoną pracę.

Tabela 1. Traktowanie pracy jako ciężaru a odpłatność za pracę

\begin{tabular}{|l|c|c|c|c|c|c|}
\hline \multirow{2}{*}{$\begin{array}{c}\text { Czy praca jest dla Pana/i ciężarem, } \\
\text { przykrym obowiązkiem? }\end{array}$} & \multicolumn{6}{|c|}{ Odpłatność za pracę (N=203) } \\
\cline { 2 - 7 } & \multicolumn{2}{|c|}{ odpłatna } & \multicolumn{2}{c|}{ nieodpłatna } & \multicolumn{2}{c|}{ ogółem } \\
\cline { 2 - 7 } & $\mathrm{N}$ & $\%$ & $\mathrm{~N}$ & $\%$ & $\mathrm{~N}$ & $\%$ \\
\hline Zdecydowanie tak & 2 & 1,9 & 2 & 2,0 & 4 & 2,0 \\
\hline Raczej tak & 5 & 4,9 & 6 & 6,0 & 11 & 5,4 \\
\hline Trudno powiedzieć & 5 & 4,9 & 6 & 6,0 & 11 & 5,4 \\
\hline Raczej nie & 31 & 30,1 & 32 & 32,0 & 63 & 31,0 \\
\hline Zdecydowanie nie & 60 & 58,2 & 54 & 54,0 & 114 & 56,2 \\
\hline Ogółem & 103 & 100 & 100 & 100 & 203 & 100 \\
\hline
\end{tabular}

Źródło: badania własne.

Okazuje się, że brak gratyfikacji finansowej nie przesądza o postrzeganiu zatrudnienia jako przykrego obowiązku. 88,3\% osób otrzymujących wynagrodzenie i $86 \%$ pracujących nieodpłatnie ocenia, że praca nie stanowi dolegliwości (odpowiedzi „zdecydowanie nie” i „raczej nie”). Wyniki badań przeprowadzonych przez Dorotę Pstrąg także pokazują, że skazani deklarują chęć podjęcia pracy, której nie traktują jako dodatkowej dolegliwości. Najczęściej kierują się motywem ekonomicznym, co wskazuje na instrumentalne traktowanie pracy, ale ważna jest sama chęć podjęcia zatrudnienia przez osoby, które nie miały okazji do wykształcenia w sobie prawidłowych nawyków pracy ${ }^{37}$.

Istotny dla założonego problemu badawczego jest rozkład odpowiedzi respondentów w zależności od tego, czy praca została im narzucona, czy podjęta na ich prośbę. Ze względu na różnice w liczebnościach grupy nie są porównywane ${ }^{38}$.

36 W przypadku zmiennej niezależnej „odpłatność za pracę” 7 respondentów nie zadeklarowało, czy pracują za wynagrodzeniem czy bez wynagrodzenia.

37 D. Pstrąg, Praca w procesie readaptacji społecznej skazanych, s. 162.

38 Różnice w liczebności grup są znaczne: 77 osób podjęło pracę wskutek decyzji przełożonych, administracji więziennej, natomiast 133 osoby samodzielnie wnioskowało o możliwość podjęcia pracy. Warto jednak zwrócić uwagę na rozkład odpowiedzi w poszczególnych grupach, który odzwierciedla ich stosunek do prezentowanego zagadnienia. 
Wykres 1. Traktowanie pracy jako ciężaru przez osadzonych, którym praca została zlecona (dane w \%, N=77)

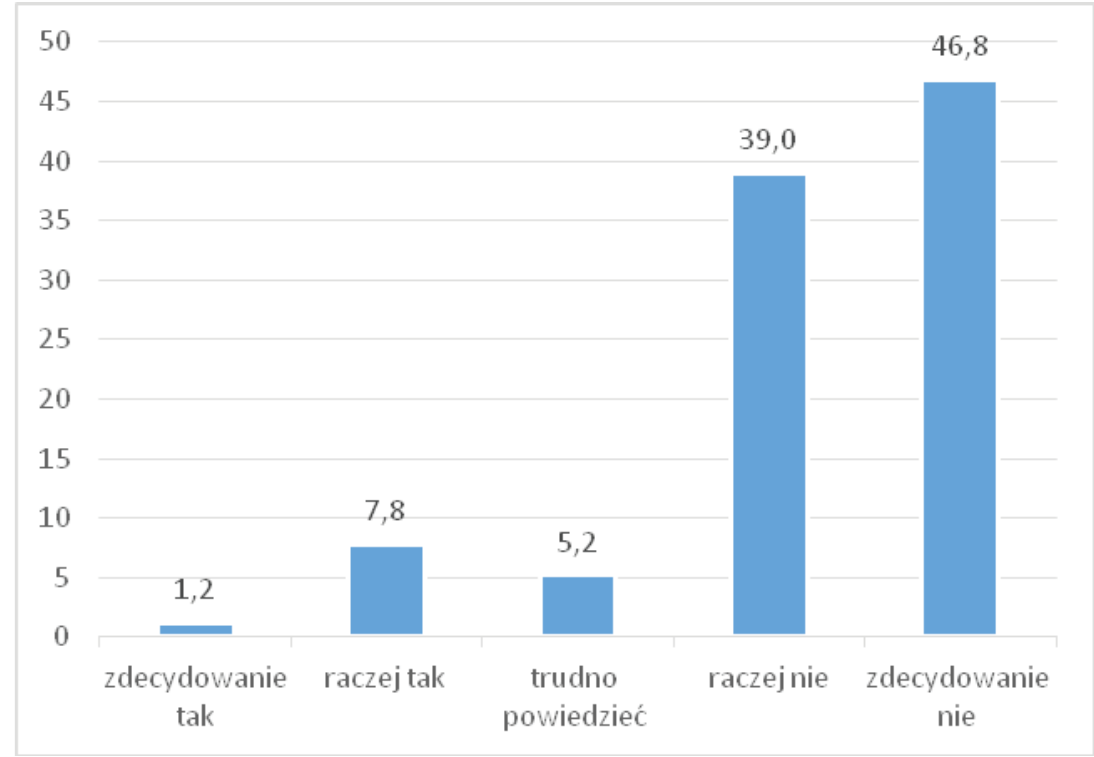

Źródło: badania własne.

Wykres 2. Traktowanie pracy jako ciężaru przez osadzonych, którzy podjęli są z własnej inicjatywy (dane $w \%, N=133$ )

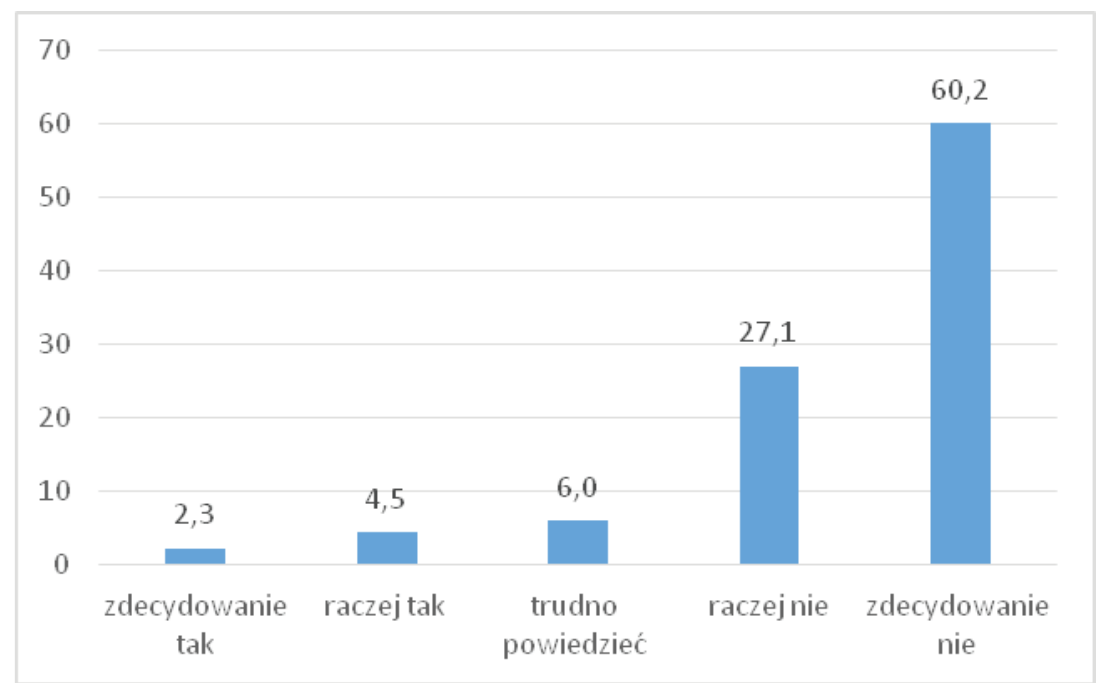

Źródło: badania własne. 
Zarówno osadzeni skierowani do pracy, jak i ci, którzy się do niej zgłosili, w większości nie traktują jej jako ciężaru. Wśród więźniów, którym zlecono pracę, tylko 9\% uznaje ją za dolegliwość, natomiast aż 85,8\% nie postrzega jej $\mathrm{w}$ ten sposób. Podobnie wyniki prezentują się w drugiej grupie. Jedynie $6,8 \%$ respondentów, którym umożliwiono pracę na ich wniosek, uważa, że praca stanowi ciężar, 87,3\% nie traktuje jej zaś jako uciążliwości. Warto podkreślić, że osoby pracujące na własne życzenie częściej wyrażały stanowczą opinię, iż praca nie jest przykrym obowiązkiem (60,2\% wskazań „zdecydowanie nie”, podczas gdy w grupie osób, którym zlecono pracę za opcją „zdecydowanie nie" opowiedziało się 46,8\% badanych). Można by się spodziewać, że skazani, w imieniu których administracja więzienna decyduje o konieczności pracy, będą w tej kwestii wyrażali niezadowolenie, ale wyniki tego nie potwierdzają. Nie ma zatem podstaw, by powołując się na zrealizowane badania określać pracę jako uciążliwą dla osadzonych podejmujących obowiązki zawodowe.

Warto też rozważyć spojrzenie na pracę z innej perspektywy. Czy w takim razie osadzeni traktują ją jako przywilej i są w stanie czerpać z niej radość? 69,5\% wszystkich ankietowanych deklaruje, że praca stanowi dla nich przywilej (odpowiedzi „zdecydowanie tak” i „raczej tak”), a 20\% badanych nie uważa pracy za przywilej (odpowiedzi „zdecydowanie nie” $i$ „raczej nie”, $\chi 2$ =97,667; p=0,000).

Tabela 2. Traktowanie pracy jako przywileju a odpłatność za pracę

\begin{tabular}{|l|c|c|c|c|c|c|}
\hline \multirow{2}{*}{$\begin{array}{c}\text { Czy praca jest dla Pana/i przywile- } \\
\text { jem, radością? }\end{array}$} & \multicolumn{6}{|c|}{ Odpłatność za pracę (N=203) } \\
\cline { 2 - 7 } & \multicolumn{2}{|c|}{ Odpłatna } & \multicolumn{2}{c|}{ Nieodpłatna } & \multicolumn{2}{c|}{ Ogółem } \\
\cline { 2 - 7 } & $\mathrm{N}$ & $\%$ & $\mathrm{~N}$ & $\%$ & $\mathrm{~N}$ & $\%$ \\
\hline Zdecydowanie tak & 36 & 35,0 & 16 & 16,0 & 52 & 25,6 \\
\hline Raczej tak & 44 & 42,7 & 47 & 47,0 & 91 & 44,8 \\
\hline Trudno powiedzieć & 11 & 10,7 & 11 & 11,0 & 22 & 10,8 \\
\hline Raczej nie & 8 & 7,8 & 16 & 16,0 & 24 & 11,8 \\
\hline Zdecydowanie nie & 4 & 3,9 & 10 & 10,0 & 14 & 6,9 \\
\hline Ogółem & 103 & 100 & 100 & 100 & 203 & 100 \\
\hline
\end{tabular}

Źródło: badania własne.

Okazuje się, że występują nieznaczne różnice w postrzeganiu pracy jako przywileju w zależności od tego, czy jest ona wykonywana za wynagrodzeniem. Osadzeni, którzy otrzymują pieniądze za świadczoną pracę, częściej deklarują, że jest ona dla nich przywilejem, niż osoby pracujące nieodpłatnie $(77,7 \%$ wobec $63,0 \%)$. Co ciekawe, $86 \%$ pracujących nieodpłatnie deklarowało, że praca nie stanowi przykrego obowiązku, ale jako przywilej i radość jest traktowana przez 
63\% tej grupy. Badania Marty Wilk z 2011 roku pokazują, że pracę traktowano instrumentalnie. Tylko 8\% respondentów uważało wówczas pracę za pewien przywilej, wartośćs ${ }^{39}$. Jednocześnie praca jako przywilej była ceniona bardziej przez więźniów ze średnim i wyższym wykształceniem, najmniej przez osoby legitymujące się wykształceniem podstawowym i bez wykształcenia ${ }^{40}$. Z kolei wyniki badań przeprowadzonych przez Elizę Mazur w latach 2014-2015 wskazują, że $61,67 \%$ badanych miało pozytywny stosunek do zatrudnienia, zaś negatywny - 38,33\% ${ }^{41}$. W miarę upływu czasu, a także położenia nacisku na pracę więźniów, zyskała ona na wartości w opinii skazanych.

Równie istotną kwestią wymagającą analizy jest chęć porzucenia zatrudnienia przez więźniów. Gdyby to od nich zależało i gdyby mieli możliwość zdecydowania, ponad 3/4 ankietowanych nie przestałoby pracować (79\%), niezależnie od tego, czy podjęli pracę z własnej inicjatywy, czy została ona im narzucona $\left(\chi^{2}=178,857 ; \mathrm{p}=0,000\right)$.

Tabela 3. Chęć rezygnacji z pracy a sposób podjęcia decyzji o pracy i odpłatność za pracę

\begin{tabular}{|c|c|c|c|c|c|c|}
\hline \multirow{3}{*}{$\begin{array}{l}\text { Czy gdyby Pan/i mógł/mogła, to } \\
\text { chętnie przestał(a)by Pani(i) pra- } \\
\text { cować? }\end{array}$} & \multicolumn{4}{|c|}{ Decyzja o podjęciu pracy $(\mathrm{N}=210)$} & & \\
\hline & \multicolumn{2}{|c|}{$\begin{array}{l}\text { Zlecona przez } \\
\text { przełożonych }\end{array}$} & \multicolumn{2}{|c|}{$\begin{array}{l}\text { Podjęta z włas- } \\
\text { nej } \\
\text { inicjatywy }\end{array}$} & \multicolumn{2}{|c|}{ Ogółem } \\
\hline & $\mathrm{N}$ & $\%$ & $\mathrm{~N}$ & $\%$ & $\mathrm{~N}$ & $\%$ \\
\hline Zdecydowanie tak & 3 & 3,9 & 6 & 4,5 & 9 & 4,3 \\
\hline Raczej tak & 6 & 7,8 & 6 & 4,5 & 12 & 5,7 \\
\hline Trudno powiedzieć & 8 & 10,4 & 15 & 11,3 & 23 & 11,0 \\
\hline Raczej nie & 19 & 24,7 & 34 & 25,6 & 53 & 25,2 \\
\hline Zdecydowanie nie & 41 & 53,2 & 72 & 54,1 & 113 & 53,8 \\
\hline \multirow[t]{4}{*}{ Ogółem } & 77 & 100 & 133 & 100 & 210 & 100 \\
\hline & \multicolumn{4}{|c|}{ Odpłatność za pracę (N=203) } & \multirow{2}{*}{\multicolumn{2}{|c|}{ Ogółem }} \\
\hline & \multicolumn{2}{|c|}{ odpłatna } & \multicolumn{2}{|c|}{ nieodpłatna } & & \\
\hline & $\mathrm{N}$ & $\%$ & $\mathrm{~N}$ & $\%$ & $\mathrm{~N}$ & $\%$ \\
\hline Zdecydowanie tak & 4 & 3,9 & 5 & 5,0 & 9 & 4,4 \\
\hline Raczej tak & 3 & 2,9 & 6 & 6,0 & 9 & 4,4 \\
\hline
\end{tabular}

${ }^{39}$ M. Wilk, Znaczenie pracy w opiniach uwięzionych, w: Tożsamość osobowa dewiantów a ich reintegracja społeczna, cz. I, red. A. Kieszkowska, Kraków 2011, s. 418.

40 Tamże, s. 419.

${ }^{41}$ E. Mazur, Resocjalizacja przez pracę w percepcji osób odbywajacych karę pozbawienia wolności, w: Współczesne problemy i perspektywy więziennictwa, red. A. Nawój-Śleszyński, A. Leszczyńska, Łódź 2019, s. 120. 


\begin{tabular}{|l|c|c|c|c|c|c|}
\hline & \multicolumn{2}{|c|}{ odpłatna } & \multicolumn{2}{c|}{ nieodpłatna } & \multicolumn{2}{c|}{ ogółem } \\
\hline Trudno powiedzieć & 12 & 11,7 & 11 & 11,0 & 23 & 11,3 \\
\hline Raczej nie & 23 & 22,3 & 27 & 27,0 & 50 & 24,6 \\
\hline Zdecydowanie nie & 61 & 59,2 & 51 & 51,0 & 112 & 55,2 \\
\hline Ogółem & 103 & 100 & 100 & 100 & 203 & 100 \\
\hline
\end{tabular}

Źródło: badania własne.

Wyniki przeprowadzonych badań pokazują, że chęć ewentualnej rezygnacji $\mathrm{z}$ pracy przez osobę pozbawioną wolności nie zależy od tego, czy podjęła ją wskutek własnej decyzji, czy została do niej przydzielona. Wyniki w grupach są zbliżone: 77,9\% osób, którym pracę zlecono i 79,7\% podejmujących ją z własnej inicjatywy nie ma zamiaru porzucić obowiązków zawodowych.

Co więcej, ewentualna rezygnacja z pracy przez ankietowanych nie zależy od otrzymywanego wynagrodzenia. Zarówno więźniowie, którzy wykonują odpłatną pracę, jak i ci, którzy wynagrodzenia nie otrzymują, deklarują, iż nie przestaliby pracować (odpowiednio 81,5\% i 78,0\%).

\section{Podsumowanie}

Dotychczasowe badania na temat pracy osób pozbawionych wolności koncentrowały się między innymi na kwestii motywacji do niej, przygotowania, roli pracy i chęci jej podejmowania po opuszczeniu zakładu karnego. W podjętych analizach skoncentrowano się na próbie określenia, czy praca stanowi wartość w opinii pracujących osadzonych. Na podstawie zaprezentowanych badań można stwierdzić, że możliwość podjęcia pracy podczas wyroku ma dla więźniów duże znaczenie.

Pierwsza hipoteza, zakładająca, że więźniowie nieotrzymujący wynagrodzenia częściej traktują pracę jako uciążliwość niż więźniowie pracujący odpłatnie, została sfalsyfikowana. Otrzymywanie lub brak wynagrodzenia za wykonywane zadania nie różnicuje respondentów pod względem postrzegania pracy jako przykrego obowiązku. Poza tym okazuje się, że zarówno w grupie więźniów, którym praca została narzucona przez administrację, jak i wśród osób podejmujących ją z własnej inicjatywy, zdecydowanie przeważają deklaracje, iż praca nie stanowi uciążliwości. Jednocześnie osadzeni otrzymujący wynagrodzenie częściej traktują pracę jako przywilej w porównaniu z osobami, które nie dostają pensji.

Druga hipoteza również została sfalsyfikowana. Zarówno osadzeni, których przydzielono do pracy, jak i dobrowolnie ją podejmujący, nie są skłonni do rezygnacji z pracy. Zaleca się jednak ostrożność w porównywaniu tych grup ze 
względu na rozbieżności w liczebnościach. Z pracy nie chcieliby zrezygnować w podobnym stopniu ci, którzy świadczą ją odpłatnie, jak i nieodpłatnie.

Wyniki przeprowadzonych badań pozytywnie rzutują na możliwości i potrzebę rozwoju pracy osób pozbawionych wolności. Nie jest ona przykrym obowiązkiem, tylko przywilejem, a osoby, które ją podejmują, nie są skłonne z niej zrezygnować. Dzięki temu możliwe jest prowadzenie oddziaływań penitencjarnych ukierunkowanych na wzmacnianie pozytywnych postaw wobec pracy wśród inkarcerowanych.

Z dostępnych badań wynika, że choć istnienie resocjalizacji poddawane jest dyskusji, to osoby pozbawione wolności akceptują możliwość podjęcia pracy jako środek kształtowania ich postaw ${ }^{42}$. Niewątpliwie odpłatność za pracę, także wykonywaną przez osoby pozbawione wolności, sprzyja przeciwdziałaniu recydywie. Wyniki badań dotyczących wpływu pracy na poczucie sensu życia skazanych, którzy odbywają kary długoterminowe pokazują, że odpłatność za pracę wpływa na poziom akceptacji siebie, afirmacji życia i poczucie wolności. Otrzymywanie wynagrodzenia za wykonywane zadania ma duże znaczenie w kształtowaniu poczucia sensu życia: sprzyja optymizmowi życiowemu i przekonaniu o swojej wartości i odpowiedzialności ${ }^{43}$. Co więcej, jeśli osadzeni wykonują pracę zgodną z wykształceniem, kwalifikacjami lub zainteresowaniami, postrzegają siebie oraz własne życie jako celowe i mające sens, a przez to wypełnianie codziennych obowiązków stanowi źródło satysfakcji ${ }^{44}$. Przeniesienie tego na grunt życia poza więzieniem przyczyni się do lepszej adaptacji byłego więźnia w środowisku i może zapobiec powrotowi do przestępczości.

Najwyższa Izba Kontroli w raporcie za okres 2014-2016 zwraca uwagę, że Służba Więzienna daje zatrudnienie ok. 70\% osadzonym, co czyni ją największym pracodawcą dla tej grupy. Dzięki pracy odpłatnej i nieodpłatnej podejmowanej przez więźniów na rzecz zakładów karnych i aresztów śledczych możliwe jest ich skuteczne funkcjonowanie ${ }^{45}$. Bez wątpienia praca podejmowana przez osadzonych podczas odbywania kary pozbawienia wolności jest szansą na wzmocnienie ich zdolności do znalezienia pracy po zakończeniu wyroku. Dostrzeganie efektów swojej pracy w murach więzienia i zdobywanie doświadczenia zawodowego może przyczynić się do otrzymania pracy w warunkach wolnościowych ${ }^{46}$. Są

${ }^{42}$ K. Lenart-Kłoś, Praca skazanych szansą na ich resocjalizację?, w: Gospodarka społecznie zakorzeniona. Wybrane problemy z socjologii gospodarki, red. S. Fel, Lublin 2013, s. 246.

43 A. Wróbel-Chmiel, Praca $w$ warunkach izolacji więziennej a poczucie sensu życia skazanych odbywajacych kary dtugoterminowe, „Probacja” 2017, nr 1, s. 82.

44 Tamże, s. 83.

45 Najwyższa Izba Kontroli, Zatrudnianie osób pozbawionych wolności. Informacja o wynikach kontroli, Warszawa 2017, s. 10. Raport obejmował I kwartał 2016 roku.

46 Por. DG Education and Culture, A. Costelloe, T. Langelid, Prison education and training in Europe - a review and commentary of existing literature, analysis and evaluation, United Kingdom 
też jednak badania, które pokazują, że praca wykonywana przez osadzonych nie wymaga wysokich kompetencji (low skilled), przez co skazani nie dążą do podnoszenia kwalifikacji. Więźniowie wprawdzie przyznają, że wykonywana w jednostce penitencjarnej praca przynosi im korzyści, ale nie ma wpływu na ich możliwości zatrudnienia po zwolnieniu z więzienia ${ }^{47}$. Na podstawie wieloletnich doświadczeń i obserwacji rzeczywistości więziennej postuluje się podejmowanie odpowiednich działań wobec osadzonych niemal od początku ich pobytu w izolacji. Warto też zastosować podejście całościowe i w jednym miejscu gromadzić oferty pracy, ale też możliwości uzupełniania kwalifikacji i przygotowania się do rekrutacji ${ }^{48}$. Holistyczne nastawienie zwiększy efektywność oddziaływań resocjalizacyjnych i pozwoli na wzmacnianie kompetencji pracowników w obszarze pracy, co jest jednym $z$ istotnych celów do osiągnięcia w przestrzeni penitencjarnej.

\section{Bibliografia}

Baldry E. et al., A Future Beyond the Wall: Improving Post-release Employment Outcomes for People Leaving Prison. Final Report, Sydney 2018.

Bejma U., Praca jako wartość w życiu człowieka. Wybrane aspekty, „Periodyk Naukowy Akademii Polonijnej" 2015, nr 4, s. 47-73.

Bombała B., Od humanizacji i strukturalizacji pracy do upełnomocniania pracowników - aspekt etyczny, "Annales. Etyka w życiu gospodarczym” 2011, nr 1, s. 67-81.

Clemmer D., The Prison Community, New York 1940.

Clemmer D., Observations on Imprisonment as a Source of Criminality, "Journal of Criminal Law and Criminology" 1950, nr 3, s. 311-319.

DG Education and Culture, A. Costelloe, T. Langelid, Prison education and training in Europea review and commentary of existing literature, analysis and evaluation, United Kingdom 2011.

Dobrowolska D., Praca zawodowa jako wartość w życiu jednostki, w: Problematyka i metody badań nad zadowoleniem z pracy, red. A. Sarapata, Wrocław 1973, s. 9-33.

Goffman E., Charakterystyka instytucji totalnych, w: Współczesne teorie socjologiczne. T. 1, red. A. Jasińska-Kania i in., Warszawa 2006, s. 316-335.

Hamlyn B., Lewis D., Women Prisoners: A Survey of Their Work and Training Experience in Custody and on Release, London 2000.

Jaki P., Zatrudnienie skazanych w Polsce na tle porównawczym. Zagadnienia wybrane, "Przegląd Więziennictwa Polskiego" 2017, nr 95, s. 79-98.

Jan Paweł II, Laborem exercens, 1981.

Kanarek-Lizik D., Modele adaptacji skazanych do warunków więziennych - wyniki badań własnych, „Resocjalizacja Polska” 2013, nr 4, s. 193-213.

2011, s. 21; K. McEvoy, Enhancing Employability in Prison and Beyond: A Literature Review, Queen's University Belfast for NIACRO 2008.

${ }_{47}$ Por. F. Simon, C. Corbett, An Evaluation of Prison Work and Training, London 1996; B. Hamlyn, D. Lewis, Women Prisoners: A Survey of Their Work and Training Experience in Custody and on Release, London 2000.

${ }^{48}$ Por. E. Baldry et al., A Future Beyond the Wall: Improving Post-release Employment Outcomes for People Leaving Prison. Final Report, Sydney 2018, s. 43. 
Klimczak J., Prizonizacja a skazani na karę dożywotniego pozbawienia wolności, „Archiwum Kryminologii" 2017, nr 39, s. 231-248.

Lenart-Kłoś K., Praca skazanych szansq̨ na ich resocjalizację?, w: Gospodarka społecznie zakorzeniona. Wybrane problemy z socjologii gospodarki, red. S. Fel, Lublin 2013, s. 229-248.

Małek S., Prizonizacja w grupie mężczyzn odbywających karę pozbawienia wolności, „Przegląd Więziennictwa Polskiego" 2009, nr 64-65, s. 135-149.

Mazur E., Resocjalizacja przez pracę w percepcji osób odbywających karę pozbawienia wolności, w: Współczesne problemy i perspektywy więziennictwa, red. A. Nawój-Śleszyński, A. Leszczyńska, Łódź 2019, s. 115-122.

Mazurek F.J., Godność osoby ludzkiej podstawa praw człowieka, Lublin 2001.

McEvoy K., Enhancing Employability in Prison and Beyond: A Literature Review, Queen's University Belfast for NIACRO 2008.

Najwyższa Izba Kontroli, Zatrudnianie osób pozbawionych wolności. Informacja o wynikach kontroli, Warszawa 2017.

Ossowski S., Z zagadnień psychologii społecznej. Dzieła. T. 3, Warszawa 1967.

Paterline B.A., Orr D., Adaptation to Prison and Inmate Self-Concept, „Journal of Psychology and Behavioral Science" 2016, nr 2, s. 70-79.

Pstrąg D., Praca w procesie readaptacji społecznej skazanych, "Lubelski Rocznik Pedagogiczny" 2014, nr 33, s. 148-164.

Roczna Informacja Statystyczna za rok 2019, online: https://sw.gov.pl/strona/statystyka-roczna [dostęp: 25 maja 2020].

Roczna Informacja Statystyczna za rok 2015, online: https://sw.gov.pl/strona/statystyka-roczna [dostęp: 25 maja 2020].

Rodzina - jej znaczenie i rozumienie. Komunikat z badań CBOS, 2019, nr 22.

Simon F., Corbett C., An Evaluation of Prison Work and Training, London 1996.

Stępień J., Socjologia pracy i zawodu, Poznań 2001.

Strzeszewski Cz., Katolicka nauka społeczna, Lublin 1994.

Sztumski J., Socjologia pracy, Katowice 1999.

Sztumski W., Nieklasyczne podejście do pracy i bezrobocia, w: Praca a bezczynność zawodowa, red. Z. Stachowski, Tyczyn 2004, s. 23-35.

Ustawa z dnia 6 czerwca 1997 r. - Kodeks karny wykonawczy (Dz.U. 1997 nr 90 poz. 557).

Wiatrowski Z., Praca jako wartość uniwersalna i jako problem XXI wieku, w: Praca człowieka jako kategoria współczesnej pedagogiki, red. W. Furmanek, Rzeszów-Warszawa 2007.

Wilk M., Znaczenie pracy w opiniach uwięzionych, w: Tożsamość osobowa dewiantów a ich reintegracja społeczna, cz. I, red. A. Kieszkowska, Kraków 2011, s. 411-421.

Woźniak Z., Programy i strategie polityki społecznej dla grup ryzyka, Warszawa 2019.

Wróbel-Chmiel A., Praca w warunkach izolacji więziennej a poczucie sensu życia skazanych odbywajacych kary długoterminowe, „Probacja” 2017, nr 1, s. 69-89.

Zalecenia Rec (2006)2 Komitetu Ministrów do państw członkowskich Rady Europy w sprawie Europejskich Reguł Więziennych przyjęte przez Komitet Ministrów w dniu 11 stycznia 2006 r. na 952 posiedzeniu delegatów.

\section{Wartość pracy dla pracujących osób pozbawionych wolności}

\section{Streszczenie}

Celem artykułu jest przedstawienie wartości pracy w opinii pracujących osób pozbawionych wolności. Na początku zaprezentowano rozumienie pracy jako wartości, podkreślając jednoczenie konieczność ujmowania jej holistycznie, wielowymiarowo. Praca stanowi obecnie jeden z najważniejszych środków resocjalizacji. Dzięki niej możliwe jest przeciwdziałanie prizonizacji, która zachodzi w instytucji 
totalnej, jaką jest zakład karny. Wyniki badań pokazują, że pracujący osadzeni nie traktują pracy jako uciążliwego obowiązku, lecz raczej jako przywilej. Nie chcieliby także zrezygnować z pracy, jaką wykonują. Nie ma znaczenia, czy sami się zgłosili do pracy, czy została im zlecona i czy otrzymują wynagrodzenie.

Słowa kluczowe: praca, więźniowie, wartość pracy, prizonizacja

\section{The value of labour for working prisoners}

\section{Summary}

The aim of this paper is to present the value of labour in the opinion of working prisoners. Work as a value has been presented and its understanding in the holistic way as a multidimensional process has been underlined. Nowadays labour is perceived as one of the most important instruments of resocialization. It enables reducing prisonization in total institutions. The results of the research show that the working prisoners treat labour as a privilege rather than a duty. They would not like to leave their job, no matter whether they have applied for it on their own or it has been commissioned to them and whether they receive a salary.

Keywords: labour, prisoners, value of work, prisonization 